\title{
PERUBAHAN LAHAN PERMUKIMAN DI KECAMATAN BEO KABUPATEN TALAUD
}

\author{
Reinaldi Wangke $^{1}$ Maxi Tendean ${ }^{2}$ Helena Sri Sulastriningsih, ${ }^{3}$ \\ ${ }^{1}$ Mahasiswa Program Studi Geografi, Fakultas Ilmu Sosial, Universitas Negeri Manado \\ ${ }^{2,3}$ Program Studi Geografi, Fakultas Ilmu Sosial, Universitas Negeri Manado \\ email : reinaldiwangke17@gmail.com
}

\begin{abstract}
The increase in population and development activities results in an increase in land use for settlements in an area over a certain period of time. The research objective is to determine changes in residential land in Beo District, Talaud Regency from 2014 to 2019. The research method is descriptive qualitative with an analytical approach using a geographic information system. Based on data processing, the land area for the residential area of Beo District in 2014 was $139.7 \mathrm{Ha}$ and in 2019 it was $149.1 \mathrm{Ha}$. The results of data analysis show that changes in residential land in Beo District, Talaud Regency from 2014 to 2019 have increased, amounting to 9.4 Ha. The rate of land change for settlements in the Beo sub-district within the 5 year period is still classified as very low.
\end{abstract}

Keywords: Land Change, Settlements, Geographical Information Systems

\begin{abstract}
Abstrak: Meningkatnya jumlah penduduk dan aktivitas pembangunan mengakibatkan bertambahnya penggunaan lahan untuk permukiman suatu wilayah pada kurun waktu tertentu. Adapun tujuan penelitan, yaitu untuk mengetahui perubahan lahan permukiman di Kecamatan Beo Kabupaten Talaud tahun 2014 sampai dengan tahun 2019. Metode penelitian adalah deskriptif kualitatif dengan pendekatan analisis menggunakan sistem informasi geografis. Berdasarkan pengolahan data, luas lahan permukiman Kecamatan Beo pada tahun 2014 sebesar 139,7 Ha dan tahun 2019 sebesar 149,1 Ha. Hasil analisis data menunjukan perubahan lahan permukiman di Kecamatan Beo Kabupaten Talaud tahun 2014 s/d 2019 mengalami penambahan, sebesar 9,4 Ha. Tingkat perubahan lahan permukiman di kecamatan beo dalam jangka waktu 5 tahun tersebut, tergolong sangat rendah.
\end{abstract}

Kata kunci: Perubahan Lahan, Permukiman, Sistem Informasi Geografis

\section{PENDAHULUAN}

Sumber daya lahan yang terdapat dalam suatu wilayah, pada dasarnya merupakan modal dasar pembangunan yang perlu dikaji dan dimanfaatkan dengan memperhatikan karakteristiknya. Karakteristik lahan yang kompleks membuat terjadi persaingan dalam penggunaan lahan untuk berbagai aktivitas. Secara ekonomis, persediaan lahan bersifat tetap, sedangkan tuntutannya terus bertambah seiring dengan dinamika perkembangan wilayah. Pertumbuhan kebutuhan lahan didorong oleh pertumbuhan penduduk, pendapatan, dan tingkat migrasi penduduk yang berasal dari wilayah lain (Anwar dalam Anjulian, L. dan Nurman, A., 2012).

Undang-Undang Nomor 1 Tahun 2011, tentang perumahan dan kawasan permukiman menyebutkan bahwa perumahan dan kawasan permukiman adalah suatu kesatuan sistem yang terdiri atas pembinaan penyelenggaraan kawasan permukiman, pemeliharaan, perbaikan, pencegahan, dan peningkatan kualitas terhadap perumahan dan permukiman, penyediaan tanah, pendanaan dan sistem pembiayaan serta peran masyarakat.

Lahan permukiman merupakan sebidang tanah yang dibangun oleh penduduk untuk menjadi tempat tinggal, saranan perkantoran, perdagangan dan olahraga. Lahan permukiman sangat dibutuhkan oleh manusia untuk berlindung dan melakukan segala aktivitas. Lahan permukiman semakin bertambah karena permukiman pada saat ini merupakan investasi yang menguntungkan, sehingga banyak penduduk yang membangun permukiman untuk 